\title{
KOMPATIBILNOST POMORSKOG I CESTOVNOG PROMETA VELEBITSKOG PODGORJA
}

\author{
Čedomir Dundović \\ Pomorski fakultet Sveučilišta u Rijeci \\ Studentska 2 \\ HR 51000 Rijeka \\ dundovic@pfri.hr \\ Damian Dundović \\ Nacionalna središnjica za usklađivanje \\ traganja i spašavanja na moru \\ Senjsko pristanište 3 \\ HR 51000 Rijeka \\ dundovic@net.hr \\ Kristina Dundović \\ Veleučilište u Rijeci \\ Vukovarska 58 \\ HR 51000 Rijeka \\ kdundovic@veleri.hr
}

UDK: 656.1(497.5 Velebit)

Izvorni znanstveni članak

Ur.: 2016-11-28

Značajka područja Velebitskog podgorja je oštro naglašeni planinski okvir koji se bez prijelaznih zona približava moru i Kvarnerskom arhipelagu. Bitno obilježje Velebitskog podgorja na neplodnom kraškom tlu je rijetka naseljenost. Područje Velebitskog podgorja veličinom i položajem u makroprostoru jedinstveno je i neusporedivo s drugim područjima u Hrvatskoj. Temeljno određenje ovog prostora je nedostatak kritične konstelacije središnjih naselja koja bi mogla postati pokretači razvoja na lokalnoj razini. Druga odlika ovog prostora je prirodna geomorfološka, botanička i etnološka osobitost Velebita, zbog čega je u velikom dijelu površina proglašen zaštićenim, kao što je Park prirode, a zatim u užem obuhvatu i Nacionalni park "Sjeverni Velebit". Treća odlika ovog prostora je strateški značajna točka izlaska kontinentalnog prostora na more i čvorište sa smjerom koji prati obalnu liniju što predstavlja magistralni pravac Jadranske turističke ceste, a u skoroj budućnosti i jadransko - jonski smjer autoceste. Ovo područje ima i određenu tranzitnu ulogu jer se u Jablancu, Prizni i Stinici nalaze trajektni terminali preko kojih se ostvaruje promet prema Krku, Rabu i Pagu, najvećim otocima Kvarnerskog arhipelaga. Na značaj i ulogu pomorskog prometa u ovom kraju bitno je utjecala klima ovog područja. Za 
klimu velebitskog područja karakteristični su vjetrovi, posebno bura. Konfiguracija kopna uvjetuje da se smjer bure na pojedinoj točki mijenja od NE do SE i dostiže na mahove brzinu od $120 \mathrm{~km} / \mathrm{h}$. Sve ovo je razlogom što je pomorski promet u ovom području relativno slabo razvijen, posebno između naselja uz obalu, a u prilog tome govori i nedostatak luka nautičkog turizma. S obzirom na to da je za razvitak ovog područja od posebne važnosti povezanost pomorskog i cestovnog prometa kao i izgradnja odgovarajuće prometne i komunalne infrastrukture, autori u ovom radu istražuju mogućnosti izgradnje novih i uređenja postojećih luka, bolju prometnu povezanost obalnih naselja i odgovarajuće veze s planinskim područjima Velebita. Razvijeni pomorski promet i izgrađena prometna infrastruktura mogu biti akcelerator razvitka ovog područja ponajprije u domeni turizma, razvoja ekološke poljoprivrede, stočarstva, šumarstva i prerađivačke industrije, iskorištavanja obnovljivih izvora energije (vjetra), razvoja male privrede, marikulture i raznih drugih uslužnih djelatnosti.

Ključne riječi: Velebitsko podgorje, kompatibilnost, pomorski promet, cestovni promet, luke posebne namjene, luke nautičkog turizma, sigurnost prometa

\section{Uvod}

Velebit započinje na sjeverozapadu, na prijevoju Vratnik iznad Senja koji velebitski masiv dijeli od Velike Kapele, odnosno Gorskog kotara. Ukupna dužina mu je oko $145 \mathrm{~km}$, a širina se mijenja pri čemu najveća doseže $30 \mathrm{~km}$. Velebit pripada Dinarskom gorskom nizu i može se istaknuti da je njegov najveći dio na tipičnom kraškom području što određuje prirodne osobine: reljef, morfologiju, utjecaj voda, biljni i životinjski svijet i dr. Velebit se dijeli na sjeverni, srednji, južni i jugoistočni dio.

Na istočnoj strani Velebita pružaju se Gacko i Ličko polje, a na zapadnoj Jadransko more. Takav zemljopisni položaj određuje i ostale prirodne značajke Velebita, posebice klimatološke. Sjeverni Velebit se proteže od prijevoja Vratnik do prijevoja iznad Jablanca, gdje započinje srednji Velebit, koji završava između Karlobaga i Gospića.

Obala šireg područja podvelebitskog primorja je strma i kamenita, a samo mjestimično na uskim potezima završava uvalama plavina šljunka ili pijeska. Uz obalu, osim u Sv. Jurju, nema otoka ni otočića. Sve uvale u Kladi, Starigradu i Stinici imaju manje šljunčane plaže, dok je preostali dio obale kamenit. Najljepša plaža na čitavom području podvelebitskog primorja je u uvali Lukovo. U svim ovim uvalama uključujući i uvalu Žrnovnica te zaljev Zavratnica postoje uređene lučice za prihvat manjih plovila.

S obzirom na klimu ovog područja uvjeti za plovidbu i za održavanje pomorskog prometa tijekom cijele godine su nešto teži nego u drugim obalnim područjima Jadrana. U Velebitskom kanalu postoje dva toka morskih struja. Uz 
obalu Velebitskog podgorja javlja se sjeverozapadna, a duž obale jugoistočna struja. Srednja brzina morske struje u Velebitskom kanalu iznosi 0,3 - 0,5 čvora $(\mathrm{NM} / \mathrm{h})$.

Pomorski promet u području podvelebitskog primorja ima svoju dugu tradiciju. Međutim, gradnjom cestovnih prometnica i željezničke pruge te povezivanjem luke Rijeka s Europom luke podvelebitskog primorja izgubile su prometno značenje. Brodarstvo ovog kraja potpuno je nestalo, a čitav pomorski promet uglavnom se svodi na održavanje trajektnih linija na plovnim putovima: Stinica - otok Rab, Prizna - Žigljen (Stara Novalja). Na nedostatak pomorskih veza bitno utječe i loše stanje cestovne infrastrukture i funkcionalne veze između pojedinih naselja uz obalu koje su priključene na državnu cestu D8.

Za budući razvoj ovog kraja ponajprije je važna izgradnja nove i obnova postojeće cestovne infrastrukture te nužna kompatibilnost s razvitkom pomorskog prometa i izgradnjom manjeg broja luka nautičkog turizma.

\section{Povijesni razvitak brodarstva i morskih luka u Velebitskom podgorju}

Brodarstvo i promet morem od Senja do krajnje podgorske granice bilo je poznato još od prapovijesti, u rimsko doba i u bližoj povijesti..

Brodarstvo ovog kraja posebno je prisutno još za vrijeme Mletačke republike (15. st.) koja uspostavlja trgovačke ugovore s krčkim knezovima Frankopanima kao gospodarima Senja. Senj je u to doba bio najvažnija hrvatska luka u kojoj borave mletački trgovci. U Senju je tada bilo i brodogradilište za koje se potrebna drvena građa najvećim dijelom dovozila iz Velebitskih šuma. ${ }^{1}$

Osvajanje Like i Krbave od Turaka i stvaranje ličkog sandžaka u prvoj polovici 16. st. imalo je za stanovništvo podvelebitskog primorja teške posljedice. Postupno su napuštali ovo područje prelazeći u Senj ili su odlazili u riječko primorje i na susjedne otoke, gdje su nalazili sigurnije sklonište.

U tom razdoblju, posebice u drugoj polovici 16. st., uskoci iz Senja izvodili su kombinirane pomorsko - kopnene akcije tako što su se iskrcavali u podvelebitskim dragama i ulazili duboko u Velebit te se vraćali s plijenom koji su ukrcavali u svoje male brodice.

Kad je Venecija 1573. godine sklopila mir s Turcima, morala se obvezati da će svojom mornaricom spriječiti uskočke pomorske akcije, a to je izazvalo nove komplikacije između Austrije i Venecije. ${ }^{2}$

\footnotetext{
${ }^{1}$ P. ROGIĆ, $1965,41$.

${ }^{2}$ P. ROGIĆ, 1965, 43.
} 


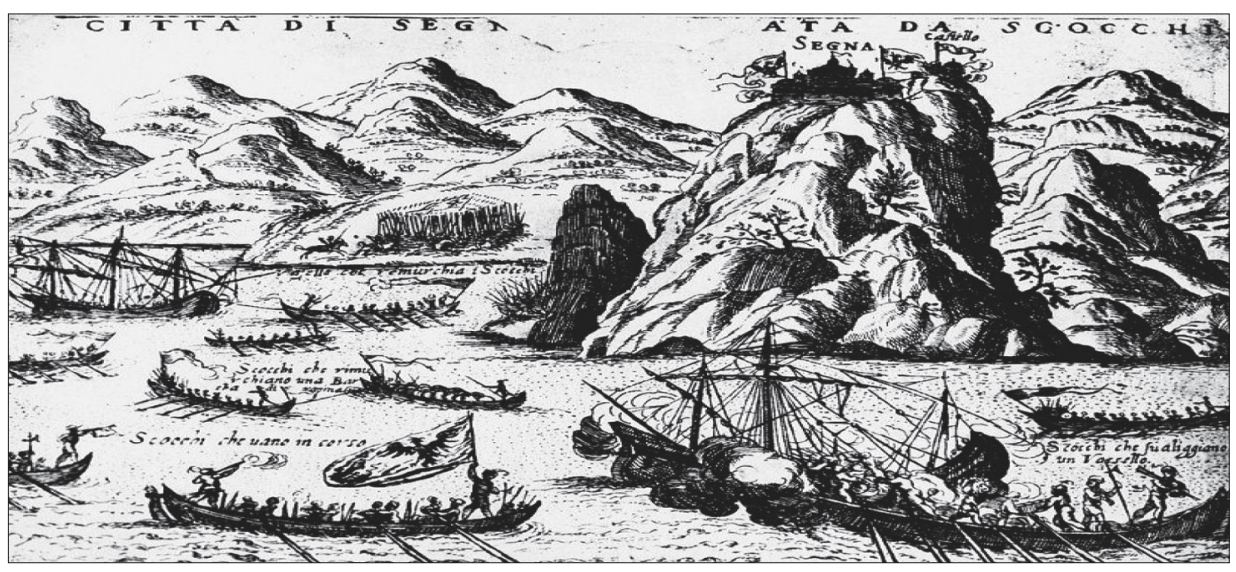

Sl. 1. Uskočki napad na mletački brod ispred Senja, XVI. st., izvor: http://www. enciklopedija.hr/Ilustracije/HE11_0773.jpg

Da bi se uspješnije mogla organizirati obrana od Turaka osnovana je 1579. Vojna krajina ili granica, tj. izdvojile su se pogranične oblasti kao posebno područje koje je bilo podređeno režimu austrijskih vojnih vlasti. Vojna krajina ostala je kao posebna austrijska pokrajina skoro tri stotine godina i tek se 1881 . ponovno sjedinila s ostalom Hrvatskom.

Međutim, i u tom razdoblju postoje određena sukobljavanja, posebno 1592. kada su Mlečani napali Karlobag pod izlikom da služi uskocima kao baza za napadaje na njihove brodove. ${ }^{3}$

Razlog tomu je bio što se rat uskoka s Turcima proširio i na uskočki rat s Mlečanima, a do njega je došlo kad je sedamdesetih godina XVI. st. Venecija sklopila mir s Turcima, razvila trgovinu s njima i stala onemogućavati uskoke, koji su se tada okrenuli protiv nje, napadajući je gdje god su mogli i na moru i na kopnu. ${ }^{4}$

Interesi Mletačke Republike, Austrije i drugih država na Jadranu i Sredozemlju sukobljavali su se oko plovidbe Jadranom. Mlečani su za sebe htjeli zadržati pravo plovidbe uz pobiranje pristojbi, a Austrija i druge države tražile su slobodnu plovidbu. Uskoci su sa svojim brzim brodicama i vičnim pomorcima (vojnicima) bili jedina snaga na području od Senja do Rijeke i dalje, koja se suprotstavljala Mletačkoj floti i onemogućavala je da bude gospodar

${ }^{3}$ P. ROGIĆ, 1965, 43.

${ }^{4}$ Š. BALEN, 1979, 27. 
Jadrana. Tek kada su Madridskim mirom uskoci raseljeni iz Senja, pokušavaju se Turci ustaliti u Podgorju.

Za vrijeme trajanja Vojne krajine (od 1579. do 1881. godine) u područje Velebitskog podgorja i primorja doseljen je veći broj stanovnika iz Senja, sjeverne Dalmacije, Vinodola i sa susjednih otoka Krka, Cresa, Lošinja, Raba i Paga. Sveti Juraj i Jablanac bile su vojničke luke u graničnom sektoru, i sva roba koja se uvozila podpadala je pod carinu. ${ }^{5} \mathrm{U}$ tom razdoblju novi doseljenici su bili podvrgnuti vojnoj disciplini i stezi te je primjenjivan niz strogih administrativnih mjera kojima se ograničavala sloboda primorskih graničara. Tako se npr. 1764. godine naređuje da se lov tuna i skuša daje u zakup, nitko ne smije loviti niti ribariti u zakupljenom prostoru, a pravo na lov i ribolov dobivaju oficiri na terenu svojeg područja. ${ }^{6}$ Poslije razvojačenja Vojne krajine 1881. život se u naseljima velebitskog podgorja odvijao bez većih promjena. Živjelo se od poljoprivrede, stočarstva i eksploatacije šuma te prijevoza drva do mora.

U naseljima uz more veći broj, posebice mlađih, stanovnika zapošljava se na brodovima i parobrodima kao članovi posade ili su radili kao lučki radnici na skladištu drva.

Prema Hainovoj analizi iz 1849. godine brodarski udio Senja i Podgorja u trgovačkoj mornarici tadašnje monarhije iznosio je $2,49 \%$ u brodovima i $0,66 \%$ u tonama nosivosti. ${ }^{7}$ Takav pomorski promet bio je rezultat poslovanja jakih uvozno - izvoznih tvrtki uglednih senjskih veletrgovaca.

Osim Senja brodarstvo je bilo dobro razvijeno i u Sv. Jurju, Lukovu, Kladi, Starigradu, Jablancu, Stinici i Karlobagu. Posebno je bilo zastupljeno u Karlobagu, jer su na njega bila orijentirana naselja južno od Karlobaga: Lukovo Šugarje, Došen i Devčić Draga, Barić Draga i dr. Brigu o stanju i razvoju pomorskog prometa ( brodarstva i luka) vodila je Trgovačka i privredna komora osnovana u Senju 1875. godine. ${ }^{8}$

Poseban oblik trgovine Podgoraca bio je i sa stanovnicima otoka $s$ kojima su razmjenjivali proizvode. Prodavali su stoku i drvenu građu i kupovali brodove. U nekim selima uz more bilo je brodova koliko i dimova, kao npr. u Barić Dragi. Uglavnom su imali bracere na jedra nosivosti 1,5 do 2 tone. ${ }^{9}$ Svaku dobro zaštićenu dragu i uvalu koristili su za vezanje svojih brodica. U

\footnotetext{
${ }^{5}$ P. ROGIĆ, 1965, 63.

${ }^{6}$ P. ROGIĆ, 1965, 45.

${ }^{7}$ A. LEMIĆ, 2013, 84.

${ }^{8}$ A. LEMIĆ, 2013, 85.

${ }^{9}$ A. LEMIĆ, 2013, 86.
} 


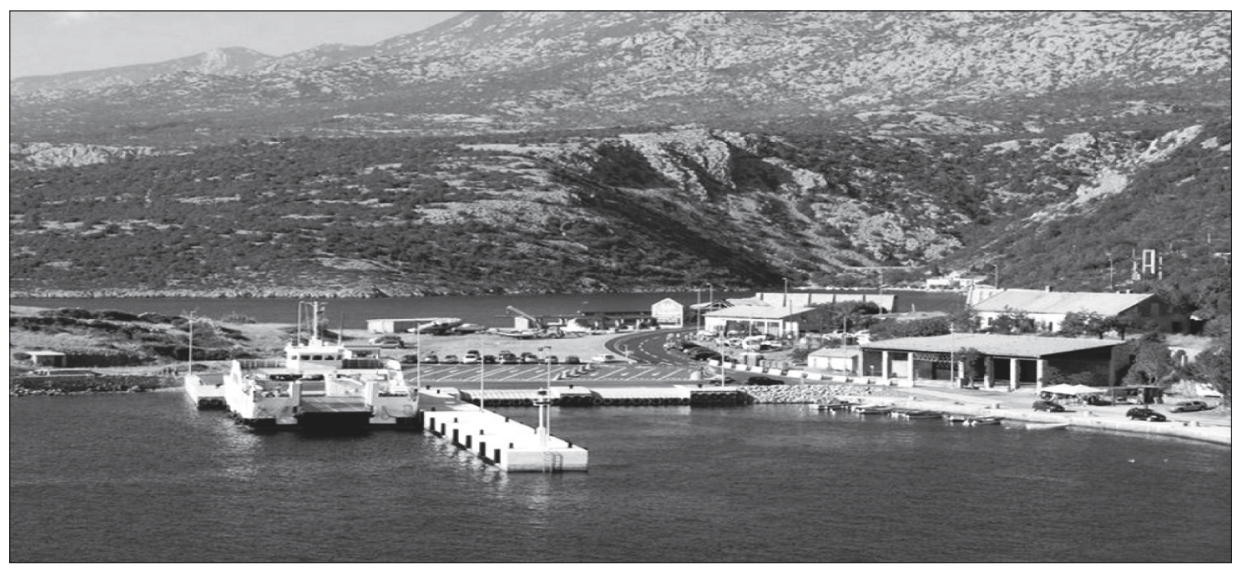

Sl. 2. Trajektno pristanište Stinica, izvor: http://www.apartmanirab.net/de/trajektalinija-prema-pagu-odvijat-ce-se-iz-pristanista-stinica/315/66

mnogim primorskim selima Podgorja i danas stoje isklesane kamene kolone i bitve. Podgorsko i senjsko brodarstvo doživjelo je krizu prelaskom brodarstva s jedrenjaka na parobrode. Ova kriza znatno je pojačana u drugoj polovici 19. st. kada je Mađarska otela Hrvatskoj Rijeku, izgradila prugu i pretvorila je u svoju najveću luku, što je uništilo Senj, dotad vodeću luku Hrvatskog primorja.

Kriza koja je tada zahvatila Senj nužno se odrazila na čitavo Podgorje, što je vidljivo i pri njegovu naglom padu brodarstva. Tako npr. dok je još 1887. godine Jablanac imao 26 brodova s 360 registarskih tona i 75 članova posade, godine 1892. ima svega 3 broda s 47 registarskih tona i 10 članova posade. ${ }^{10}$

Tendencija nestajanja podgorskog brodarstva nastavila se i nadalje, posebice nakon Drugog svjetskog rata kada se nije smjelo imati privatne brodove, pa su ih i oni preostali prodali.

$\mathrm{Na}$ tom području pomorske veze održavali su brodovi na relaciji Rijeka Obrovac, Rijeka - Pag i Rijeka - Rab.

U bližoj prošlosti pomorski promet u Velebitskom podgorju svodi se na trajektne veze između obale i obližnjih otoka. U mreži morskih prometnih putova redovite su dvije stalne trajektne linije za Rab i Pag (pristaništa Jablanac, Stinica i Prizna). Premještanjem trajektnog pristaništa iz Jablanca u Stinicu, omogućeno je da se Jablanac zadrži kao rezervna luka za javni promet.

U povijesnom kontekstu luke Podgorja spominju se još u izvješću senjskog kapetana Hansa Albrechta von Herbersteina 1639. godine koji navodi popis

${ }^{10}$ Š. BALEN, 1979, 48. 
luka od Senja do Dračevca (gdje se nalazila granica s mletačkim posjedima) s posebnim naglaskom na luke "utvrde" Jablanac i Starigrad. ${ }^{11}$

U suvremenim uvjetima luke Velebitskog podgorja svrstane su u javne luke županijskog značaja (Senj, Jablanac, Ptizna, Stinica) te javne luke lokalnog značaja (Sv. Juraj, Donja Klada, Starigrad, Lukovo, Krivača).

Na području Velebitskog podgorja postoji i određeni broj manjih lučica (sportske luke) za čuvanje brodica domicilnog stanovništva.

Ono što svakako nedostaje u području Velebitskog podgorja su luke nautičkog turizma, koje bi mogle biti jedan od generatora razvoja ovog područja.

\section{Povijesni razvitak i ocjena postojećeg stanja prometnica Velebitskog podgorja}

Prvi zapisi o prometnim vezama na području Velebitskog podgorja datiraju još iz rimskog doba. Propašću Rimskog Carstva zapuštene su i propale sve te ceste. Nakon oslobađanja od Turaka na prijelazu iz 17. na 18. stoljeće uspostavljene su trgovačke veze po zapuštenim i propalim putovima. Prva prava cesta u Podgorju od Senja do Sv. Jurja izgrađena je 1785. godine (Vukasovićeva cesta). Do Karlobaga je produžena 1874., a tek 1924. godine nastavljena je do Obrovca. ${ }^{12}$

U 18. stoljeću izgrađene su i šumske ceste - vlake, koje su u narodu poznate pod nazivom ceste Marije Terezije, kao ona od Sv. Jurja preko Oltara do Krasna što je predstavljalo važnu prometnu vezu na ovom području.

Prometne veze su u prošlosti bitno utjecale na razvitak Velebitskog podgorja koje je suštinski bilo vezano za razvoj i sudbinu Senja. Nakon izgradnje prve planski trasirane ceste (Karolina 1726.) koja je povezala slobodnu riječku luku s Karlovcem, gradi se Jozefinska cesta od Karlovca preko Oštarija i Vratnika do Senja (1775 - 1779). Sve do 1810. godine kad je dovršena Lujzinska cesta, Senj je uspio zadržati konkurenciju Rijeci u lučkom prometu i podjeli trgovačkog utjecaja u hrvatskom zaleđu. Na koji je način potiskivan utjecaj Senja u njegovom širem zaleđu poslije 1810. godine teško je pouzdano utvrditi, ali ključan pomak u zaostajanju Senja bila je izgradnja i otvaranje željezničke pruge 1873. godine. ${ }^{13}$

Ograničenjem senjske gravitacijske zone na uzak pojas rijetko naseljenog, gospodarski slabo razvijenog Velebitskog podgorja, potpuno je izmijenjena

\footnotetext{
${ }^{11}$ Š. BALEN, 1979, 29.

${ }^{12}$ A. LEMIĆ, 2013, 84.

${ }^{13}$ V. ROGIĆ, 1965, 18.
} 


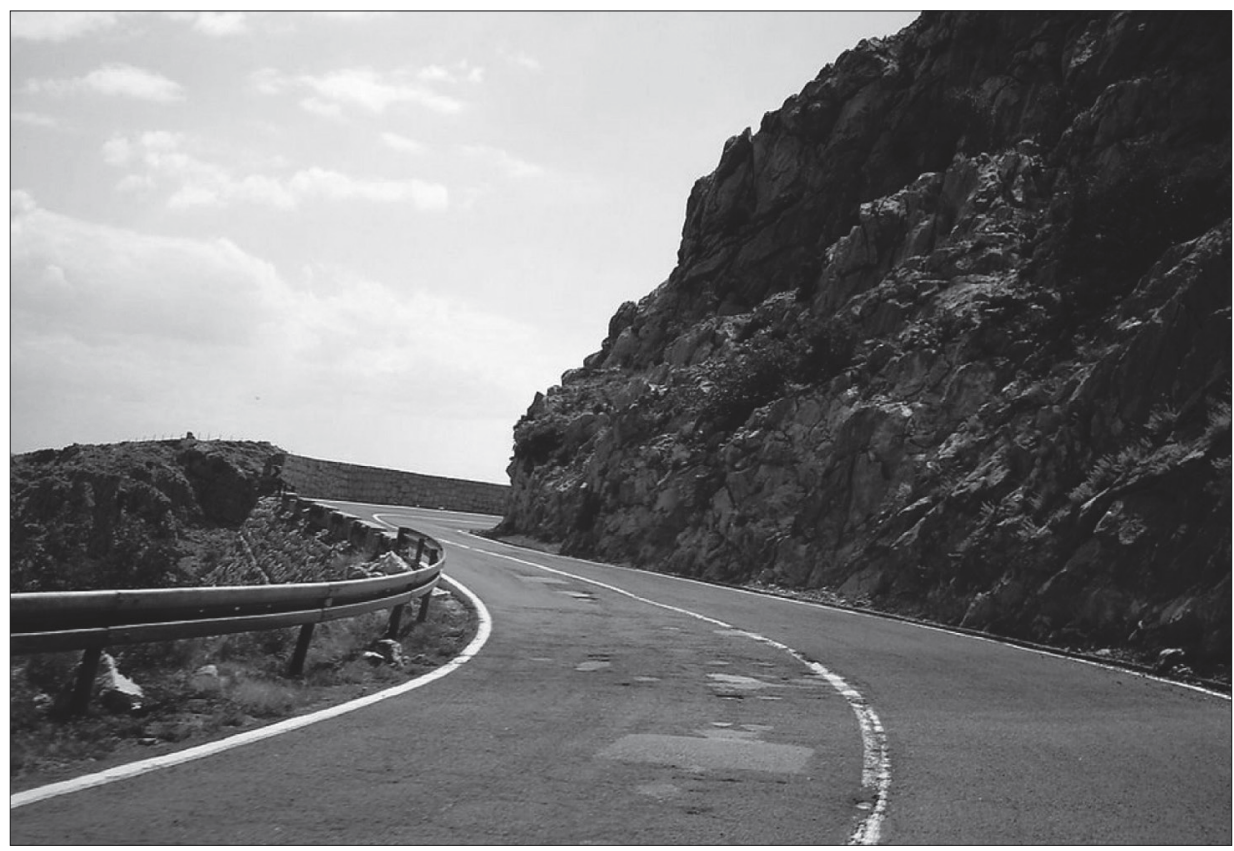

S1.3. Jadranska magistrala, izvor: http://static.panoramio.com/photos/large/ 12054059.jpg

njegova geografska funkcija te nastavljeno daljnje zaostajanje Senja i Velebitskog podgorja.

Za razvitak Velebitskog podgorja poseban značaj imala je izgradnja cestovne prometnice (D8) popularno zvane magistrala. Ova prometnica pruža se uzdužnim jadransko - jonskim smjerom i već je poprilično zastarjela.

U području Velebitskog podgorja evidentiran je nedostatak odgovarajućih cestovnih prometnica. Ovim područjem osim državne ceste D8 Rijeka - Senj - Zadar (Jadranska magistrala) prolazi državna cesta D405 - D8 (Jablanac trajektna luka) i D406 - D8 (Prizna - trajektna luka) te županijske ceste: Ž5126 Sv. Juraj (D8) - Krasno Polje - Velika Plana - Smiljan - Gospić (D25), Ž5140 - Krasno Polje (Ž5126) - Švica - Otočac (D50) i Ž5182 Jablanac - Bileni Štirovača (Ž5 126). ${ }^{14}$

Osim ovih cestovnih prometnica postoje i lokalne ceste kao npr.: Lukovo - D8, Anići - Krasno, D405 - Stinica i Zavratnica - D8.

\footnotetext{
${ }^{14}$ Prostorni plan uređenja grada Senja, 2012, 20-21.
} 


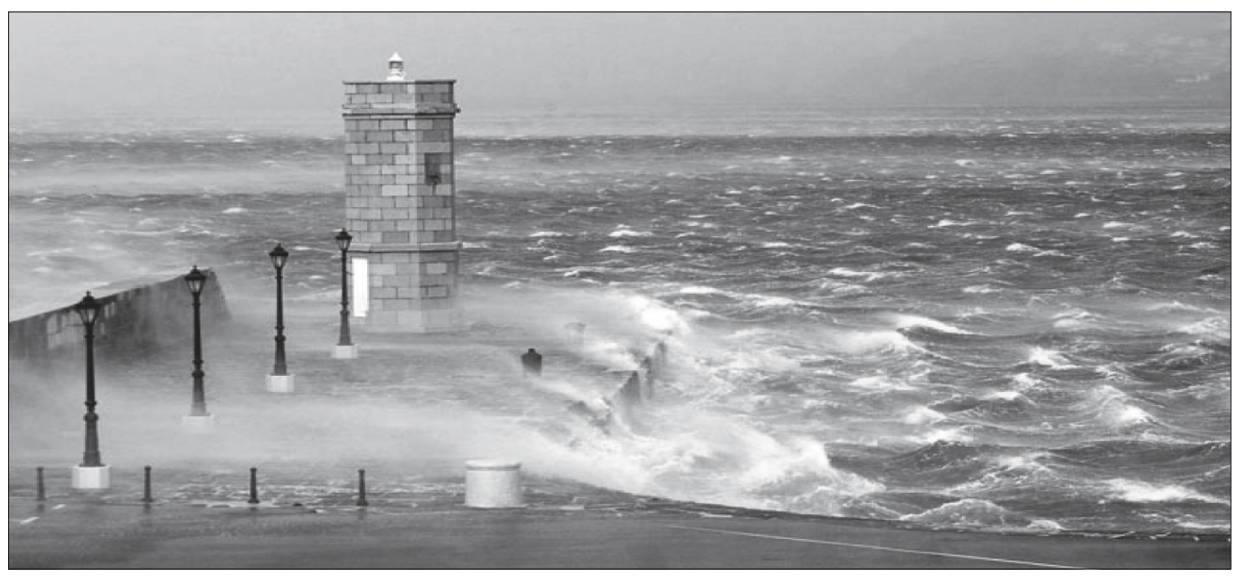

Sl. 4. Bura u Senju, izvor: http://forum.net.hr/cfs-filesystemfile.ashx/_key/ CommunityServer.Discussions.Components.Files/14/4604.SENJSKA_2500_20BURA.jpg

Međutim, sve ove cestovne prometnice, uključujući i državne i županijske ceste u vrlo su lošem stanju, pogotovo u planinskim predjelima. To se posebno odnosi i na županijsku cestu Ž51832 koja preko Velebita povezuje Jablanac s Perušićem i Gospićem, jer ta cesta ima važan turistički potencijal te je bitna i kao tranzitna cesta koja povezuje Liku s priobaljem.

Sve ovo upućuje na potrebu izgradnje novih i moderniziranje postojećih cestovnih prometnica ukoliko se želi potaknuti razvitak ovog kraja.

\section{Perspektive razvitka pomorskog prometa i luka u Velebitskom podgorju}

Razvitak pomorskog prometa u razvojnim planovima grada Senja i Ličko - senjske županije na području Velebitskog podgorja uglavnom se zasniva na daljnjem održavanju trajektnih linija za otoke Rab i Pag (pristaništa Stinica, Jablanac i Prizna) te ponovnom uspostavljanju linije za Krk (Senj - Baška). Osim poprečnih veza u sustavu pomorsko - putničkog prometa u planskim smjernicama predlaže se i stvaranje uvjeta za uspostavu stalne veze među naseljima kvarnerskog i podvelebitskog obalnog pojasa (Rijeka - Crikvenica Senj - Karlobag - Starigrad) te brze i frekventne čarter veze na lokalnoj razini na području grada Senja i Velebitskog podgorja tijekom cijele godine (češće u ljetnim mjesecima). Ove su pomorske veze funkcionirale u prošlosti, dok cestovna veza još nije bila razvijena. ${ }^{15}$

${ }^{15}$ Prostorni plan uređenja grada Senja, 2012, 113. 
Tablica 1. Postojeći i planirani kapacitet luka nautičkog turizma prema prostornim planovima županija

\begin{tabular}{|l|c|c|c|c|c|c|}
\hline \multirow{2}{*}{ ŽUPANIJA } & \multicolumn{3}{c|}{ POSTOJEĆI (2013.) } & \multicolumn{2}{c|}{ NOVOPLANIRANI (2015.) } \\
\cline { 2 - 8 } & $\begin{array}{c}\text { U } \\
\text { MORU }\end{array}$ & $\begin{array}{c}\text { NA } \\
\text { KOPNU }\end{array}$ & UKUPNO & $\begin{array}{c}\text { U } \\
\text { MORU }\end{array}$ & $\begin{array}{c}\text { NA } \\
\text { KOPNU }\end{array}$ & UKUPNO \\
\hline Istarska & 3668 & 802 & 4470 & 7330 & 7100 & 14430 \\
\hline Primorsko - goranska & 3455 & 1803 & 5258 & 3100 & 0 & 3100 \\
\hline Ličko - senjska & - & - & - & 850 & 800 & 1650 \\
\hline Zadarska & 3553 & 1221 & 4774 & 1800 & 0 & 1800 \\
\hline Šibensko - kninska & 3529 & 938 & 4467 & 2140 & 0 & 2140 \\
\hline Splitsko - dalmatinska & 2021 & 503 & 2524 & 3185 & 0 & 3185 \\
\hline Dubrovačko - neretvanska & 714 & 206 & 920 & 7350 & 0 & 7350 \\
\hline \multicolumn{1}{|c|}{ UKUPNO } & 16940 & 5473 & 22413 & 25755 & 7900 & 33655 \\
\hline
\end{tabular}

Izvor: Državni zavod za statistiku, http://www.dzs.hr (27.01.2016.)

Za razvitak pomorskog prometa na području Velebitskog podgorja posebno je važan razvitak nautičkog turizma. Na cijelom ovom području do danas nije izgrađena ni jedna luka nautičkog turizma. S obzirom na značaj nautičkog turizma u razvojnim planovima Republike Hrvatske vrlo je bitno da se na ovom obalnom području Velebitskog podgorja izgrade manje luke nautičkog turizma, koje mogu potaknuti razvoj turizma u ovom kraju.

U Tablici 1. dan je prikaz postojećih i novoplaniranih kapaciteta luka nautičkog turizma u Republici Hrvatskoj.

Razlozi zbog kojih do danas nema izgrađenih luka nautičkog turizma u podvelebitskom primorju ponajprije se opravdavaju klimatskim uvjetima (jak vjetar), maritimnim ograničenjima i značajkama obale koja nije razvedena $\mathrm{i}$ nema otoka uz obalu.

Na temelju podataka Nacionalne središnjice za usklađivanje traganja i spašavanja - MRCC Rijeka (Tablica 2.) može se utvrditi da su akcije traganja i spašavanja uzrokovanih jakim vjetrom u razdoblju od 2011. do 2015. godine na području Lučke kapetanije Senj u odnosu na Lučku kapetaniju Rijeka češće, bez obzira što Lučka kapetanija Rijeka ima nadležnost nad znatno većim područjem.

Za pomorski promet pored luka županijskog značaja: Senj, Jablanac i Prizna, te luka lokalnog značaja: Sv. Juraj, Donja Klada, Starigrad, Lukovo, Stinica (Mala Stinica) od posebnog značaja je i izgradnja luka nautičkog 
Tablica 2. Usporedba akcija spašavanja uzrokovanih vjetrom na području LK Senj i LK Rijeka

\begin{tabular}{|c|c|c|c|c|c|}
\hline & 2011. & 2012. & 2013. & 2014. & 2015. \\
\hline $\begin{array}{c}\text { Lučka kapetanija Senj } \\
\text { (ukupno SAR akcija uzrokovanih vjetrom) }\end{array}$ & 5 & 7 & 8 & 7 & 6 \\
\hline $\begin{array}{c}\text { Lučka kapetanija Rijeka } \\
\text { (ukupno SAR akcija uzrokovanih vjetrom) }\end{array}$ & 5 & 10 & 2 & 3 & 5 \\
\hline
\end{tabular}

Izvor: Nacionalna središnjica za usklađivanje traganja i spašavanja - MRCC Rijeka

Tablica 3. Vodene površine za luke posebne namjene

\begin{tabular}{|c|c|c|c|}
\hline Lokalitet & Površina akvatorija & Kapacitet & Izgrađeno/neizgrađeno \\
\hline Senj & 1,8 ha & do 200 vezova u moru & Neizgrađeno \\
\hline Krivača (Stinica) & 4,4 ha & do 200 vezova u moru & Izgrađeno/neizgrađeno \\
\hline Lukovo & 1,2 ha & do 50 vezova u moru & Neizgrađeno \\
\hline Starigrad & 0,5 ha & do 50 vezova u moru & Izgrađeno/neizgrađeno \\
\hline Sv. Juraj (Jablanova) & 4,8 ha & do 50 vezova u moru & Izgrađeno/neizgrađeno \\
\hline
\end{tabular}

Izvor: Prostorni plan uređenja grada Senja, 1. Polazišta, Sveučilište u Zagrebu, Arhitektonski fakultet, Zagreb, 2012., 75 .

turizma i sportskih luka. Vodene površine u funkciji rekreacije u Prostornom planu uređenje Grada Senja određene kao luke nautičkog turizma i sportske luke u pravili se nalaze $u$ akvatoriju izgrađene javne luke, uz novu organizaciju korištenja akvatorija ili njegovo proširenje.

Kapaciteti predviđenih luka posebne namjene usklađeni su s Uredbom o zaštićenom obalnom pojasu (Tablica 3.).

Osim ovih luka, Planom su određene i lokacije za sportske luke (Senj i Sv. Juraj) te ribarske luke (Senj, Sv. Juraj i Jablanac) koje čine dio organizacijske cjeline lučkog sustava. Planom je također potrebno odrediti potencijalne lokacije za privezišta i sidrišta kao mjesta za sklonište brodica i moguće intervencije na obalnoj liniji od lokalnog značaja. Izgradnja privezišta je moguća jedino u područjima naselja, a sidrišta samo pod uvjetom da je njihova pozicija objavljena u pomorskim publikacijama. Postojeća privezišta za smještaj do 10 plovila izvan luke javne namjene nalaze se u Gradu Senju, u uvali Žrnovnica, a planirana sidrišta su: uvale Vlaška I, Ždralova, Vlaška II, Vela Ivanča i Bočanje Vele.

Za razvitak nautičkog turizma u Velebitskom podgorju od posebnog značaja je ravnoteža između očuvanja prirodnih i prostornih vrijednosti te 
izgradnje i eksploatacije luka nautičkog turizma, što mora biti i osnovni cilj prilikom izrade prostornih planova.

S obzirom na to da nautički turizam u kombinaciji s gorskim (seoskim, sportsko - rekreativnim, lovnim i zdravstvenim) turizmom može biti jedan od pokretača razvoja ovog kraja u planovima razvoja zaslužuje posebnu pozornost.

Za razvitak pomorskog prometa i nautičkog turizma od posebne važnosti je kopnena prometna povezanost luka i odgovarajućih turističkih sadržaja (novi turistički kompleksi, plaže, rekreacijski centri i sl.). Izgradnjom novih i proširenjem postojećih cestovnih prometnica, ali i drugim prometnim vezama (obnova žičarskog prijevoza) potrebno je osigurati prostornu povezanost obalnog i gorskog područja Velebitskog podgorja. Sve ovo ukazuje na potrebu kompatibilnog razvitka pomorskih i kopnenih prometnih veza i turističkih sadržaja koji mogu potaknuti i razvitak drugih djelatnosti.

\section{Kompatibilnost razvitka prometne infrastrukture i pomorskog prometa Velebitskog podgorja}

Gospodarske i društvene aktivnosti planirane na području Velebitskog podgorja trebaju predstavljati osnovu društveno ekonomskog razvitka i poticaj reverzibilnim procesima demografskog oporavka. Gospodarske aktivnosti treba poticati u onim dijelovima prostora gdje postoji radno aktivno stanovništvo, ali i stvarati uvjete za dolazak novih stanovnika, posebice onih koji su morali iz ekonomskih razloga napustiti ovaj kraj, uključujući i njihove potomke koji mogu pridonijeti razvitku ovog područja. U tom smislu važno je istaknuti značaj buduće autoceste Križišće - Žuta Lokva te Jadransko - jonske ceste kao nositelja koridorskog razvoja što može dati poticaj razvoju zapostavljenih područja.

U idućem razdoblju očekuje se razvitak turizma kao visokoproduktivne djelatnosti koja danas prolazi kroz preobrazbe interesnih osnova turističke potrošnje, mijenjanja turističkih navika, želja i očekivanja koja više nisu orijentirana prvenstveno prema sezonskom turizmu uz more, nego i prema kombinacijama i najrazličitijim prostornim atrakcijama.

Uz buduću autocestu Križišće - Žuta Lokva koji može biti propulzivni nositelj koridorskog razvoja i poticatelj razvoja zapostavljenih područja Velebitskog podgorja treba svakako istaknuti i Jadransko - Jonsku autocestu na dionici koja prolazi područjem Grada Senja što će utjecati na prometno rješenje u kojem se problem obilaska, priključka na autocestu te spojeva na državne ceste D8 i D23 treba rješavati integralno i po mogućnosti u etapama. 


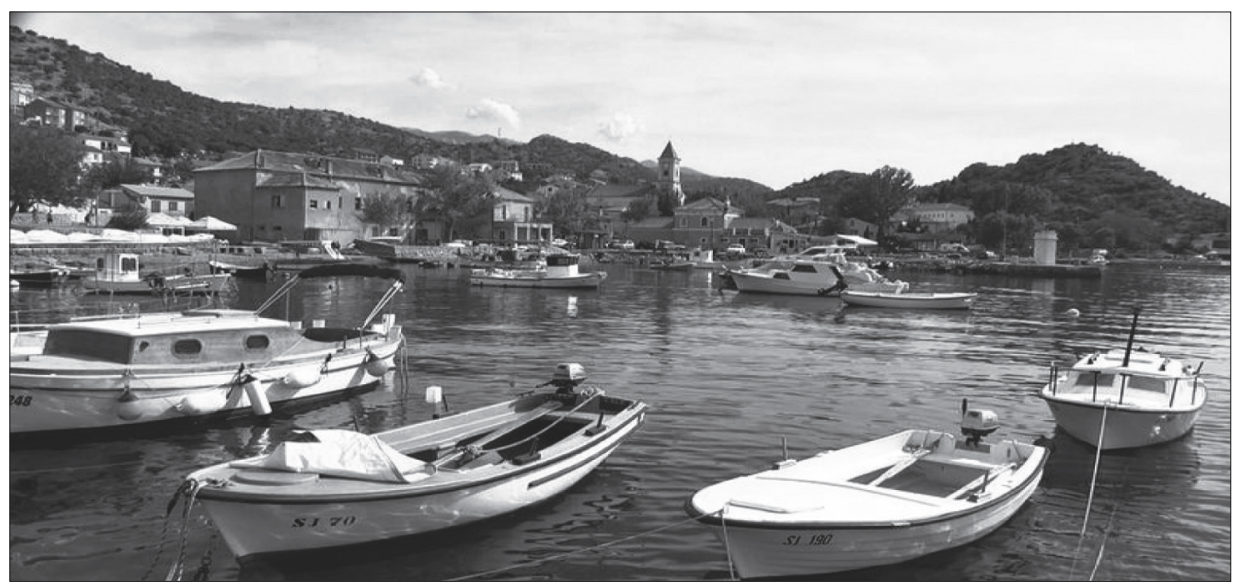

S1. 5. Sveti Juraj, izvor: http://www.topdestinacije.hr/upload_data/ckeditor/11\%20 SENJ/18.jpg

Planom je predviđena izgradnja nove dionice državne ceste prema novom trajektnom pristaništu između Jablanca i Stinice, izgradnja zaobilaznice kod Svetog Jurja te proširenje i tehnička poboljšanja cesta koje od magistrale vode do trajektnih pristaništa u Prizni i Jablancu.

Također je predviđena modernizacija (proširenje i korekcija dionice) županijske ceste Ž5182 Jablanac - Štirovača i dijela ceste Ž5126 od Štirovače prema Gospiću. ${ }^{16}$ Postojeće ceste županijskog značaja u Prostornom planu Grada Senja pružaju se poprečnim smjerovima koji povezuju obalnu zonu i Velebitsko zaleđe:

- Sveti Juraj - Oltari - Krasno - Otočac

- Jablanac / Stinica - Štirovača

te uzdužnim smjerom u zaleđu : Krasno - Štirovača - Gospić.

Velikim dijelom svojih trasa ove prometnice ne zadovoljavaju prometne standarde kategorizacije, pa ih je potrebno proširiti i tehnički modernizirati.

Slično, kao i ceste županijskog značaja i postojeća lokalna mreža cesta je zbog slabe izgrađenosti prostora neodgovarajuća. Postojeću mrežu lokalnih cesta treba proširiti i tehnički modernizirati prometnicama prema naseljenim područjima u obalnom pojasu:

- D8 - Starigrad

- D8 - Klada

- D8 - Josinovac

${ }^{16}$ Prostorni plan uređenja grada Senja, 2012, 111. 
S obzirom na turistički značaj naselja Krasno prioritet treba biti i povezivanje Krasna na državnu cestu D23, preko naselja Crni Kal, Vrzići i Melnice ili uz njih. Ostale nerazvrstane ceste u području Velebitskog podgorja predstavljaju dugačku mrežu u funkciji šumskih, požarnih ili putova posebne namjene. Planom je predviđena i izgradnja panoramske turističke ceste (povezivanjem više dionica postojećih šumskih cesta) u alternativni pravac uzduž velebitskog masiva, okrenut prema morskoj strani. Ova panoramska cesta koja bi povezivala Stolac, Biljevine, Oltare, Brisnice i Dundoviće nastavljala bi se smjerom velebitskog masiva prema Karlobagu. S obzirom da je put na nekim dionicama i danas kolno prohodan, ova cesta mogla bi se relativno brzo izgraditi s proširenjima za mimoilaženje ili zaustavljanje na atraktivnim mjestima s vidikovcima.

Za razvitak pomorskog prometa i obalnog turizma poseban značaj imaju spojne ceste od magistrale prema moru. S obzirom na konfiguraciju terena njihovo tehničko unaprjeđenje i proširenje je preduvjet daljnjih turističkih ulaganja i razvitka luka nautičkog turizma.

\section{Zaključak}

Kompatibilnost pomorskog i cestovnog prometa u Velebitskom podgorju jedan je od ključnih uvjeta za razvoj ovog kraja. Na značaj i ulogu pomorskog prometa u ovom području bitno utječe klima (veća učestalost i snaga vjetra, posebno bure) što smanjuje sezonski karakter turizma.

Zemljopisni položaj, cestovne veze s kontinentalnim zaleđem i duž obale te pomorske veze $s$ otocima davale su ovom području vrlo važan političko - ekonomski značaj. Posebna značajka ovog prostora je strateški značajno područje izlaska kontinentalnog prostora Hrvatske na more te ključno čvorište koje prati obalnu liniju (danas magistralni pravac Jadranske turističke ceste Rijeka - Zadar - Split - Dubrovnik, a u skoroj budućnosti i jadransko - jonski smjer autoceste).

Ovo područje ima i izrazito naglašenu tranzitnu ulogu, jer se u Jablancu (Stinici) i Prizni nalaze trajektni terminali preko kojih se ostvaruje pomorski promet prema Rabu i Pagu. Veći dio obalnog pojasa je kamenit sa strmim pristupom moru i lošim pristupnim cestama.

Sve uvale u Kladi, Starigradu i Stinici imaju manje šljunčane plaže, a preostali dio je kamenit $\mathrm{s}$ mogućnošću djelomičnog korištenja zbog nemogućnosti prometnog pristupa moru. U nekim uvalama kao što su npr. uvale Žrnovnica i Grabova ima mnogo vrulja pa je more hladnije za kupanje. 
Poseban nedostatak u području Velebitskog podgorja je nedostatak luka nautičkog turizma. Ličko - senjska županija je jedina županija u kojoj ove luke još uvijek nisu izgrađene.

Međutim, upravo izgradnja luka nautičkog turizma s ograničenim brojem plovila te povezivanje obalnog i gorskog područja Velebita može biti važan pokretač razvitka ovog kraja.

Pored razvitka nautičkog turizma bitan razvojni potencijal može biti i određivanje lokacija za razvoj marikulture.

Radi toga je potrebno prometno povezati obalno područje i Velebitsko gorje, obnoviti postojeće i izgraditi nove cestovne prometnice, proširiti postojeće prometnice prema naseljima na obali, te poticati razvoj turističkih kapaciteta na obali, ali i u gorskim krajevima (razvitak zdravstvenog, zimskog, seoskog i lovnog turizma).

Jedan od načina prometnog povezivanja obalnih i gorskih predjela Velebita može biti i obnova žičarskog transporta.

Međutim, ključan naglasak treba biti na izgradnji odgovarajuće cestovne infrastrukture koja je nužna pretpostavka i za razvitak pomorskog prometa i turizma.

\section{Literatura}

Šime BALEN, Jablanac (1179 - 1979), Povijesna skica prigodom 800. obljetnice, Zagreb, 1979.

Ana LEMIĆ, Sela i stanovi na Velebitu - Svjedočanstva života od nastanka do nestanka, Zagreb, 2013.

Prostorni plan uređenja grada Senja, 1. Polazišta, Sveučilište u Zagrebu, Arhitektonski fakultet, Zagreb, 2012.

Pavle ROGIĆ, Naseljenost Velebitske primorske padine kroz historiju, Senjski zbornik, I, Senj, 1965, 35-68.

Veljko ROGIĆ, Položaj Senja i gravitacija, Senjski zbornik, I, Senj, 1965, 7-21. 


\section{THE COMPATIBILITY OF THE SEA AND ROAD TRANSPORT OF VELEBIT PODGORJE}

\section{Summary}

The feature of the region of Velebit Podgorje is the greatly accentuated mountain range, which without transitional zones it approaches the sea and the Kvarner archipelago. A significant feature of Velebit Podgorje on the infertile karst soil is its scarce inhabitation. The area of Velebit Podgorje by its size and position in the macro-region is unique and incomparable with other regions in Croatia.

The fundamental definition of this area is the lack of a critical constellation of central settlements, which could become initiators of development on the local level. Another feature of this area is the natural geomorphological, botanical and ethnological particularity of Velebit, due to which a great part of the surface area has been declared protected, such as the Nature Park, and after that with a narrower coverage the Northern Velebit National Park. The third feature of this area is the strategically significant point of the exist of the continental area to the sea and the junction with the route which follows the coastline which represents the main course of the Adriatic tourist road, and in the near future the course of Adriatic-Ionian motorway as well. This area also has a certain transit role because in Jablanac, Prizna and Stinica there are ferry terminals, which provide transport links to Krk, Rab and Pag, the largest islands of the Kvarner archipelago. The climate of this region has substantially influenced the significance and role of maritime traffic in this area. The winds are characteristic of the climate of the Velebit region, especially the 'bura'. The configuration of the land causes the direction of the 'bura' to change at a particular point from NE to SE and intermittently reach a speed of up to $120 \mathrm{~km} / \mathrm{h}$.

All of this is the reason why maritime traffic in this region is poorly developed, particularly between the settlements along the coast, and this is also evident in the lack of nautical tourism ports. Bearing in mind that for the development of this region the connectivity of sea and road transport is of special importance, as well as the building of the corresponding transport and communal infrastructure, in this paper the authors investigate the possibilities of the construction of new, as well as the improvement of, existing ports, plus the better transport connectivity of coastal settlements and the corresponding links with the mountain regions of Velebit. The developed sea transport and constructed transport infrastructure can be an accelerator of the development of this region principally in the domain of tourism, the development of ecological agriculture, livestock breeding, forestry and manufacturing industries, the exploitation of renewable sources of energy (wind), the development of small businesses, mariculture and various other service activities.

Keywords: Velebit Podgorje, compatibility, sea transport, road transport, special purpose ports, nautical tourism ports, transport safety 